\title{
A new species of Astyanax Baird \& Girard (Ostariophysi: Characidae) from the rio Taquari-Antas basin, southern Brazil
}

\author{
Vinícius A. Bertaco and Anelise C. Vigo
}

\begin{abstract}
A new Astyanax is described from the rio Taquari-Antas basin, rio Jacuí drainage, laguna dos Patos system, Rio Grande do Sul State, Brazil. The new species is distinguished from its congeners inhabiting the rio Uruguay, laguna dos Patos and rio Tramandaí basins by the presence of two vertically elongated humeral spots, the anterior humeral spot with the upper portion wider than the lower portion and slightly directed forward, 37-39 perforated scales along the lateral line, 14 scale rows around caudal peduncle, 2-4 maxillary tricuspid teeth, 24-28 branched anal-fin rays, bony hooks on all fins of mature males, and conspicuous caudal peduncle spot. Furthermore, the new species differs from its congeners by body depth (37.9-45.9\% of standard length), preanal distance (62.4-69.1\% of SL), anal-fin base length (29.7-35.6\% of SL), and orbital diameter (29.5-38.2\% of head length).

Uma nova espécie de Astyanax é descrita da bacia do rio Taquari-Antas, drenagem do rio Jacuí, sistema da laguna dos Patos, Rio Grande do Sul, Brasil. A espécie nova distingui-se das suas congêneres que habitam as bacias do rio Uruguai, laguna dos Patos e rio Tramandaí pela presença de duas manchas umerais verticalmente alongadas, a mancha anterior com a porção superior mais larga que a porção inferior e levemente direcionada a frente, 37-39 escamas perfuradas na linha lateral, 14 séries de escamas ao redor do pedúnculo caudal, 2-4 dentes tricuspidados no maxilar, 24-28 raios ramificados na nadadeira anal, ganchos ósseos em todas as nadadeiras dos machos maduros e mancha no pedúnculo caudal conspícua. Além disso, a espécie nova difere de suas congêneres pela altura do corpo (37,9-45,9\% do comprimento padrão), distânciapré-anal (62,4-69,1\% do CP), comprimento da base da nadadeira anal (29,7-35,6\% do CP) e diâmetro orbital (29,5-38,2\% do comprimento da cabeça).
\end{abstract}

Keywords: Bony hooks, Lambari, Rio Grande do Sul State, Rio Jacuí.

\section{Introduction}

Astyanax Baird \& Girard is a species-rich characid genus, composed of 145 valid species, widely distributed on the Neotropical region from southern United States to central Argentina (Eschmeyer, 2014). According to recent phylogenies Astyanax does not represent a monophyletic group (Javonillo et al., 2010; Mirande, 2010; Oliveira et al., 2011), and so far it has been defined by a combination of characters proposed nearly a century ago by Eigenmann (1921, 1927): two rows of premaxillary teeth, five teeth in the inner premaxillary series, lateral line complete, adipose fin present, and caudal fin scaleless. Nevertheless, some of these characters are also shared by other genera in the Characidae (e.g., Hemigrammus Gill, Hyphessobrycon Durbin, and Moenkhausia Eigenmann \& Eigenmann, 1921, 1927).

Presently, there are 18 recognized species of Astyanax in the main hydrographic basins of Rio Grande do Sul State (rio Uruguay, laguna dos Patos, and rio Tramandaí) (Lucena et al., 2013a, 2013b; Bertaco, 2014). During a revisionary study of Astyanax from these basins, an endemic new species was recognized from tributaries of the rio Taquari-Antas, rio Jacuí drainage, laguna dos Patos system, which is described herein.

\section{Material and Methods}

Counts were taken as described by Fink \& Weitzman (1974) and Bertaco \& Lucena (2006). Gill-rakers, supraneurals, procurrent caudal-fin rays and vertebrae were counted on cleared and stained specimens (c\&s) prepared according to Taylor \& van Dyke (1985). Vertebral counts included the four vertebrae of the Weberian apparatus and the terminal centrum was counted as a single element. Along the description counts are followed by the number of occurrence in parentheses, and the value observed on the holotype is marked with an asterisk. In listed materials, catalog numbers are followed by the total number of specimens, number of c\&s specimens in parentheses, and the range of standard length (SL) of specimens on the lot. 
Measurements were point-to-point linear distances taken using digital caliper with a precision of $0.01 \mathrm{~mm}$ on the left side of the specimen. Measurements are expressed as percentage of standard length (SL) except for subunits of the head, which are recorded as percentage of head length (HL). Sex of adult specimens was recognized by macroscopic examination of their gonads and/or by the presence or absence of bony hooks in fin rays. The diagnosis presented here follows the procedures described by Lucena et al. (2013b: 538).

Specimens examined are from the following institutions: Museu de Ciências Naturais, Fundação Zoobotânica do Rio Grande do Sul, Porto Alegre (MCN); Museu de Ciências e Tecnologia, Pontifícia Universidade Católica do Rio Grande do Sul, Porto Alegre (MCP); and Departamento de Zoologia, Universidade Federal do Rio Grande do Sul, Porto Alegre (UFRGS). The comparative material is listed in Bertaco \& Lucena $(2006,2010)$ and Lucena et al. (2013a, 2013b).

\section{Results}

\section{Astyanax bagual, new species}

urn:1sid:zoobank.org:act:119C81F9-A288-442A-94CF87EDDF25D095

Figs. 1-2

Astyanax sp. 4. -Becker et al. (2013: 82, table 1, listed, rio TaquariAntas basin).

Holotype. UFRGS 19525, $74.1 \mathrm{~mm}$ SL, male, Brazil, Rio Grande do Sul State, Dois Lageados, rio Carreiro downstream to hydroeletric plant PCH Linha Emília, rio Taquari-Antas basin, rio Jacuí drainage, laguna dos

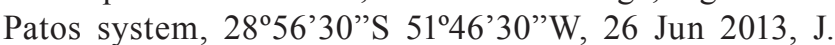
Ferrer \& J. M. Wingert.
Paratypes. All from Brazil, Rio Grande do Sul State, rio Taquari-Antas basin, rio Jacuí drainage, laguna dos Patos system: MCN 16547, 1, 56.0 mm SL, rio Forqueta, Pouso Novo, $29^{\circ} 05^{\prime} 40^{\prime \prime} \mathrm{S} 52^{\circ} 12^{\prime} 44^{\prime \prime} \mathrm{W}, 13$ Jan 2002, P. C. C. Milani. MCN 19903, 1, $71.1 \mathrm{~mm} \mathrm{SL}$, rio Turvo,

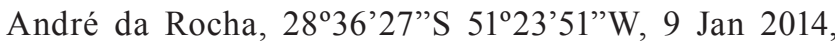
A. R. Cardoso \& G. Rosa. MCN 19915, 3, 67.6-73.2 mm SL, collected with holotype. MCP 33552, 1, $59.2 \mathrm{~mm} \mathrm{SL}$,

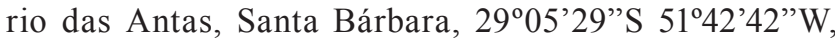
28 Sep 2002, ichthyology staff MCP. MCP 33620, 2, 63.0-66.0 mm SL, rio das Antas, Santa Bárbara, $29^{\circ} 05^{\prime} 29^{\prime}$ 'S $51^{\circ} 42^{\prime} 42^{\prime \prime} \mathrm{W}, 6$ Nov 2002, J. D. Latini. MCP $33623,1,62.7 \mathrm{~mm}$ SL, rio das Antas, Nova Roma do Sul, $29^{\circ} 00^{\prime} 40^{\circ} \mathrm{S} 51^{\circ} 22^{\prime} 22^{\circ} \mathrm{W}, 18$ Jan 2003 , J. D. Latini. MCP $33640,1,65.0 \mathrm{~mm} \mathrm{SL}$, rio das Antas, Nova Roma do Sul, $29^{\circ} 00^{\prime} 40^{\circ} \mathrm{S} 51^{\circ} 22^{\prime} 22^{\prime}$ W, 1 Oct 2002 , J. D. Latini. UFRGS 6398, 9, 56.0-78.4 mm SL, rio Carreiro, Serafina

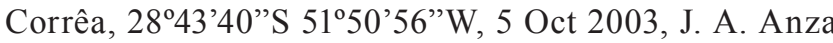
\& F. S. Villela. UFRGS 6966, 4, 63.3-76.8 mm SL, rio Carreiro, Guaporé, Oct 2003 to Jan 2005, J. A. Anza. UFRGS 8958, 3, 46.6-54.4 mm SL, rio Carreiro near to hydroeletric plant PCH Linha Emília, Dois Lageados, $28^{\circ} 56^{\prime} 30^{\prime \prime}$ S 51 46'30"W, 2 Oct 2006, J. Ferrer \& C. E. Machado. UFRGS 10437, 1, $74.1 \mathrm{~mm}$ SL, rio da Prata near mouth of arroio Jararaca, Nova Roma do Sul, $28^{\circ} 56^{\prime} 30^{\prime \prime} \mathrm{S} 51^{\circ} 26^{\prime} 30^{\prime \prime} \mathrm{W}, 10$ Sep 2008, J. Ferrer \& G. L. Frainer. UFRGS 12295, 1, $68.1 \mathrm{~mm}$ SL, rio Carreiro,

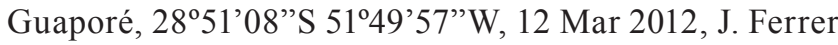
\& J. M. Wingert. UFRGS 12296, 6, 63.1-72.0 mm SL, rio Carreiro downstream to $\mathrm{PCH}$ Linha Emília, Dois

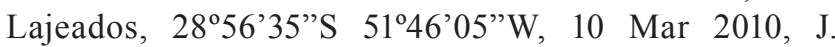
Ferrer \& J. M. Wingert. UFRGS 13733, 1, $61.5 \mathrm{~mm} \mathrm{SL}$,

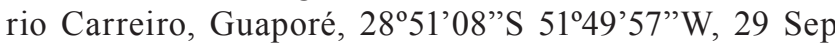
2010, V. A. Bertaco \& G. Rosa. UFRGS 17834, 7 (3 c\&s), 65.0-78.4 mm SL (+2 ethyl alcohol anhydrous), collected with holotype.

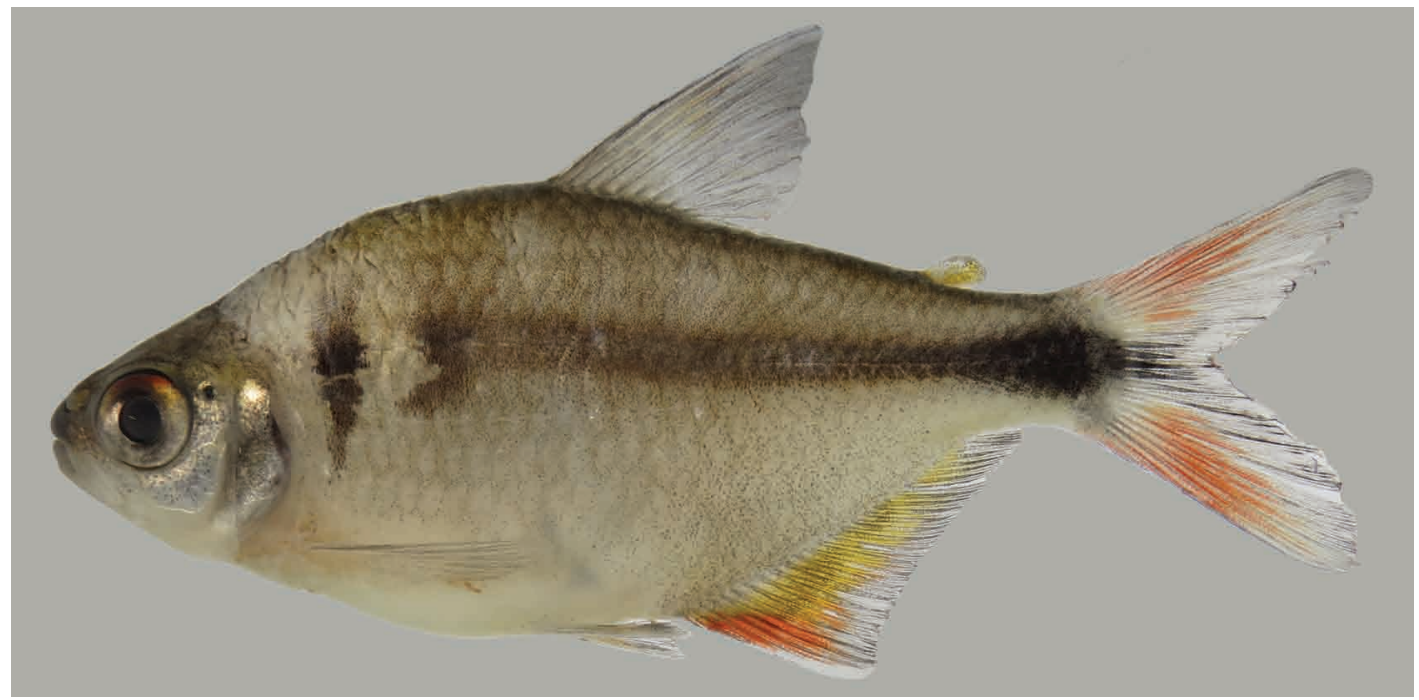

Fig. 1. Astyanax bagual, UFRGS 19525, $74.1 \mathrm{~mm} \mathrm{SL}$, male, holotype, rio Carreiro downstream to hydroeletric plant PCH Linha Emília, rio Taquari-Antas, laguna dos Patos system, Dois Lageados, Rio Grande do Sul State, Brazil. 
Diagnosis. Astyanax bagual differs from all congeners inhabiting the rio Uruguay basin, laguna dos Patos and rio Tramandaí systems by the following characters: first humeral spot vertically elongate with upper portion wider than lower portion and slightly directed forward (vs. presence of oval spot with two brown vertical bars in humeral region in A. jacuhiensis (Cope), oval spot in A. laticeps (Cope), and forming a uniform wedge in A. eigenmanniorum (Cope), A. henseli Melo \& Buckup, A. saguazu Caciotta, Almirón \& Azpelicueta and $A$. stenohalinus (Messner); two humeral spots (vs. one in $A$. eigenmanniorum, $A$. aff. fasciatus (Cuvier), $A$. jacuhiensis, and A. laticeps), 24-28 branched anal-fin rays (vs. 18 or less in A. brachypterygium Bertaco \& Malabarba and A. cremnobates Bertaco \& Malabarba, 1823 in A. procerus Lucena, Castro \& Bertaco and A. xiru Lucena, Castro \& Bertaco, 20-22 in A. paris Azpelicueta, Almirón \& Casciotta, 16-21 in A. obscurus (Hensel), 1523 in A. laticeps, 15-20 in A. pirabitira Lucena, Bertaco \& Berbigier, 20-23 in A. ojiara Azpelicueta \& Garcia; 22-24 in A. douradilho Bertaco); 2-4 maxillary tricuspid teeth (vs. one in $A$. aramburui Protogino, Miquelarena \& López, A. dissensus Lucena \& Thofehrn, and A. aff. fasciatus); 37-39 perforated scales along the lateral line (vs. 34-36 in A. paris), and 14 scale rows around caudal peduncle (vs. 15-16 in A. stenohalinus). Furthermore, $A$. bagual differs from A. douradilho and A. saguazu by body depth $(37.9-45.9 \%$ of SL, mean $=43.3 \%$ vs. 34.4$41.0 \%$ of $\mathrm{SL}$, mean $=37.0 \%$ and $30.9-39.0 \%$ of SL, mean $=35.6 \%$ ); and from A. saguazu and A. stenohalinus by preanal distance $(62.4-69.1 \%$ of SL, mean $=65.5 \%$ vs. $56.0-61.2 \%$ of SL, mean $=58.7 \%$ and $58.2-62.7 \%$ of SL, mean $=59.8 \%$ ), respectively; and from A. stenohalinus by the anal-fin origin located at vertical through last dorsal-fin ray insertions vs. before a vertical through last dorsal-fin ray insertions. The following combination of characters distinguish $A$. bagual from all others species of the genus (including the species complex $A$. bimaculatus Linnaeus and $A$. scabripinnis Jenyns): the presence of two vertically elongated humeral spots (the anterior humeral spot with upper portion wider than lower portion and slightly directed forward), 24-28 branched anal-fin rays, 37-39 perforated lateral line scales, outer row of premaxilla with tricuspid teeth, inner premaxilla row with pentacuspid teeth, 2-4 maxillary tricuspid teeth, small bony hooks on all fins of mature males, conspicuous caudal peduncle spot, body depth (37.9-45.9\% of SL), preanal distance (62.4-69.1\% of SL), anal-fin base length (29.7-35.6\% of SL), and orbital diameter $(29.5-38.2 \%$ of HL).

Description. Morphometric data summarized in Table 1. Body compressed and moderately deep, with greatest body depth anterior to dorsal-fin origin. Dorsal profile of head strongly convex from tip of snout to vertical through nostrils, straight to slightly concave from that point to tip of supraoccipital spine. Dorsal profile of body convex from tip of supraoccipital spine to base of last dorsal-fin ray; straight from thatpoint to adipose fin origin. Ventral profile of body convex from mandibular symphysis to pelvic-fin origin, nearly straight to anal-fin origin, and posterodorsally slanted along anal-fin base. Caudal peduncle deep, nearly straight on dorsal and ventral margins.

Mouth terminal, isognathous jaw. Mouth slit nearly at horizontal through middle of eye. Maxilla extending posteriorly to vertical through anterior margin of orbit, reaching pupil. Premaxillary teeth in two rows: outer row with $4 *(15), 5(9)$, or 6(4) tricuspid teeth, central cusp longer; inner row with five teeth, gradually decreasing in sizefrom first to fifth; usually with four cusps on first tooth, five cusps on second to fourth teeth and three cusps on fifth tooth. Maxilla with 2(12), 3(18), or $4 *(1)$ tri- or pentacuspid teeth; central cusp broader than others. Dentary with $4 *(31)$ large pentacuspid teeth, followed by six to nine small teeth, uni- to tetracuspid (Fig. 2). Median cusp in all cuspidate teeth longer than remaining cusps; cusp tips slightly curved lingually in dentary, premaxillary teeth cusps approximately straight.

Table 1. Morphometric data for holotype and paratypes of Astyanax bagual, $\mathrm{n}=31$ (including holotype) from the rio Taquari-Antas basin, rio Jacuí drainage, laguna dos Patos system, Rio Grande do Sul, Brazil. SD = standard deviation.

\begin{tabular}{lcccc}
\hline & Holotype & Range & Mean & SD \\
\hline Standard length (mm) & 74.1 & $46.7-78.4$ & 64.8 & - \\
Percents of Standard length & & & & \\
Predorsal distance & 54.5 & $51.7-56.2$ & 54.4 & 1.2 \\
Prepelvic distance & 48.5 & $46.5-52.2$ & 49.3 & 1.5 \\
Prepectoral distance & 27.5 & $25.4-30.4$ & 27.6 & 1.2 \\
Preanal distance & 64.8 & $62.4-69.1$ & 65.5 & 1.8 \\
Depth at dorsal-fin origin & 45.2 & $37.9-45.9$ & 43.3 & 1.9 \\
Caudal peduncle depth & 12.9 & $11.2-13.1$ & 12.3 & 0.5 \\
Caudal peduncle length & 13.0 & $10.8-13.5$ & 12.5 & 0.7 \\
Anal-fin base length & 33.4 & $29.7-35.6$ & 33.4 & 1.7 \\
Dorsal-fin length & 30.3 & $28.5-33.2$ & 30.6 & 1.3 \\
Pelvic-fin length & 18.6 & $16.2-21.0$ & 18.2 & 1.1 \\
Pectoral-fin length & 25.3 & $22.8-27.9$ & 24.7 & 1.0 \\
Head length & 26.1 & $24.9-28.8$ & 26.9 & 1.0 \\
Percents of Head length & & & & \\
Snout length & 23.8 & $20.6-25.1$ & 22.8 & 1.2 \\
Upper jaw length & 45.2 & $36.3-46.1$ & 42.5 & 2.4 \\
Orbital diameter & 33.8 & $29.5-38.2$ & 34.0 & 1.6 \\
Interorbital width & 30.7 & $24.8-31.8$ & 28.6 & 1.6 \\
\hline & & & & \\
\hline & & & & \\
\hline & & & & \\
\hline
\end{tabular}




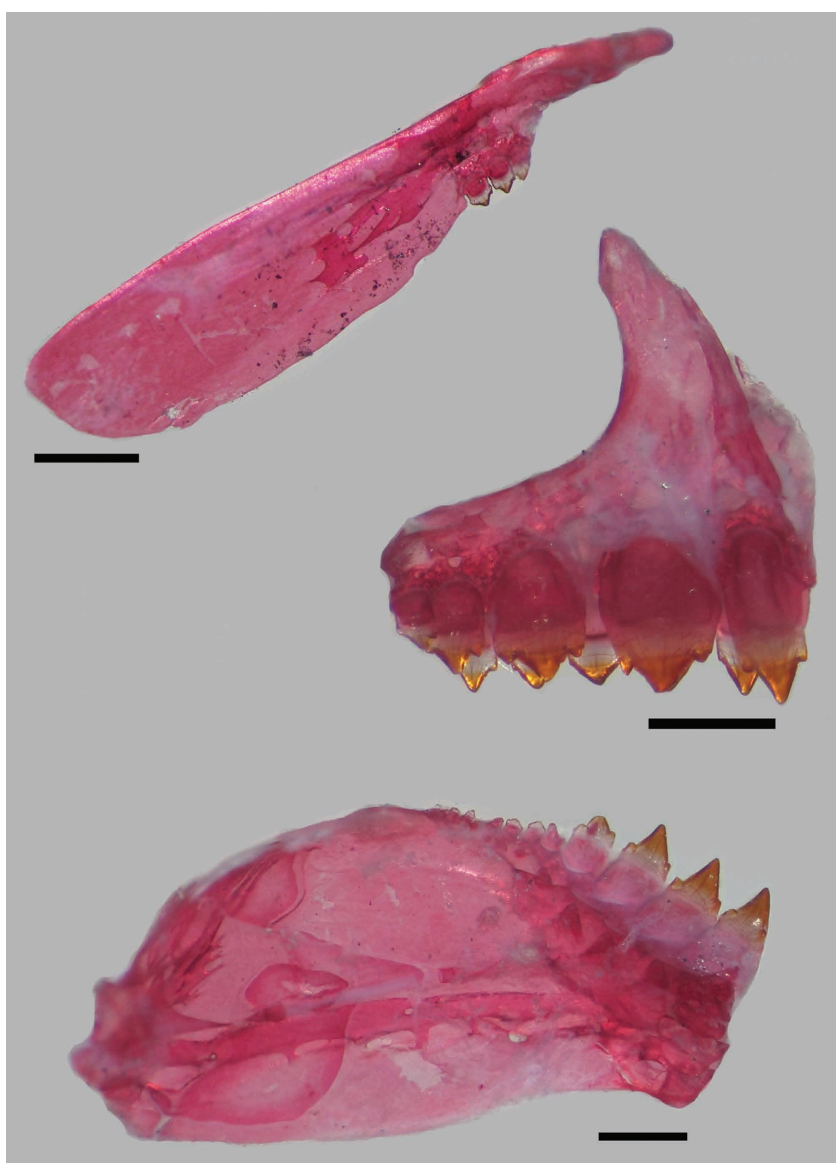

Fig. 2. Astyanax bagual, UFRGS 17834, $68.4 \mathrm{~mm}$ SL, paratype. Upper and lower jaws left side, medial view. Scale bars $=1 \mathrm{~mm}$.

Dorsal-fin rays i,10*(31); first unbranched ray approximately one-half the length of second ray. Distal margin of dorsal fin nearly straight to somewhat convex. Dorsal-fin origin slightly behind middle of SL. Adipose-fin origin at vertical through second or third last anal-fin rays. Anal-fin rays iii*(27) or iv(4), 24(4), 25*(9), 26(11), 27(4), or 28(3). Anal-fin origin posterior to vertical through base of last dorsal-fin ray. Pectoral-fin rays i,11(1), 12*(16), or 13(14). Pectoral-fin tip not reaching pelvic-fin insertion. Pelvic-fin rays $i, 7^{*}(31)$. Pelvic-fin origin slightly anterior to vertical through dorsal-fin origin. Caudal fin forked, lobes similar in size, $\mathrm{i}, 17, \mathrm{i}^{*}(30)$ principal rays. Dorsal procurrent rays 11(1) or 12(1) and ventral procurrent rays 10(1) or 11(1).

Lateral line complete with $37^{*}(24), 38(2)$, or $39(4)$ scales. Scale rows between dorsal-fin origin and lateral line $6(2), 7^{*}(27)$, or $8(2)$; scale rows between lateral line and pelvic-fin origin $5^{*}(28)$ or $6(3)$. Predorsal scales11 (12), $12 *(8)$, or 13(6) arranged in regular series. Scale rows around caudal peduncle $14 *(30)$. Scale sheath along anal-fin base 10-15 scales $14^{*}(29)$, in single series, covering base of anteriormost rays. Axilar scale longer than wide, relatively folded in half, and extending over 1-2 longitudinal scale series.
Precaudal vertebrae 15(1) or 16(2); caudal vertebrae $20(2)$ or 21(1); total vertebrae 36(2) or 37(1). Supraneurals $3(1)$ to 5(2). Gill-rakers at upper branch 7(2) or 8(1) and at lower branch 10(1) or 11(2); total number of gill-rakers 17(1), 18(1), or 19(1).

Color in alcohol. Dorsal and dorsolateral portions of head and body dark brown. Infraorbital and opercular areas covered with scattered, dark chromatophores. Scales on lateral body with dark brown chromatophores. Body with black midlateral stripe extending from second humeral spot to caudal-fin base. Caudal peduncle spot black expanded dorsally and ventrally, extending to tip of middle caudal-fin rays. Two humeral spots. Anterior one conspicuous, vertically elongate with upper portion wider, located over third to fifth vertical series of scales, extending over two to three horizontal series of scales above lateral line; lower portion of spot narrow and slightly directed forward (one to two scales pigmented), extending over one to two horizontal series of scales below lateral line. Second humeral spot large, occasionally faint, not surpassing lateral line ventrally, extending over three horizontal series and two to three vertical series of scales, and in some specimens the lower portion wider than the upper portion. Scattered dark chromatophores on dorsal, adipose, caudal, and anal fins. Pectoral and pelvic fins with few dark chromatophores. Dark pigmentation on middle caudal-fin rays and along middle-distal portion of anal-fin rays (Fig. 1).

Color in life. Color pattern similar to described for alcohol preserved specimens. Overall and head color pattern yellowish, slightly brown. Dorsolateral portion of body dark gray. Scales lateral on body silvery. Dorsal, pectoral, pelvic, and adipose fins with anterior portion yellowish and posterior reddish. Anal fin reddish at distal half of first rays and yellowish at proximal half of rays. Caudal fin almost completely reddish, except for middle yellowish portion.

Sexual dimorphism. Mature males of Astyanax bagual are recognized by the presence of small bony hooks on all fins. One paired bony hook per segment of ray in the last unbranched anal-fin ray and anteriormost anal-fin branched rays on middle and distal portions of rays. One paired bony hook per segment of ray on second to fifth pelvic-fin branched rays. Dorsal, pectoral, and caudal fins with few bony hooks dispersed in distal portions of rays. Gill glands (Burns \& Weitzman, 1996) or fusion of anteriormost gill filaments of the ventral branch of first gill arch (Terán et al., 2014) were not found macroscopically on the both mature males and females.

Distribution. Astyanax bagual is known from rio TaquariAntas basin, rio Jacuí drainage, laguna dos Patos system, Rio Grande do Sul State, southern Brazil (Fig. 3). 


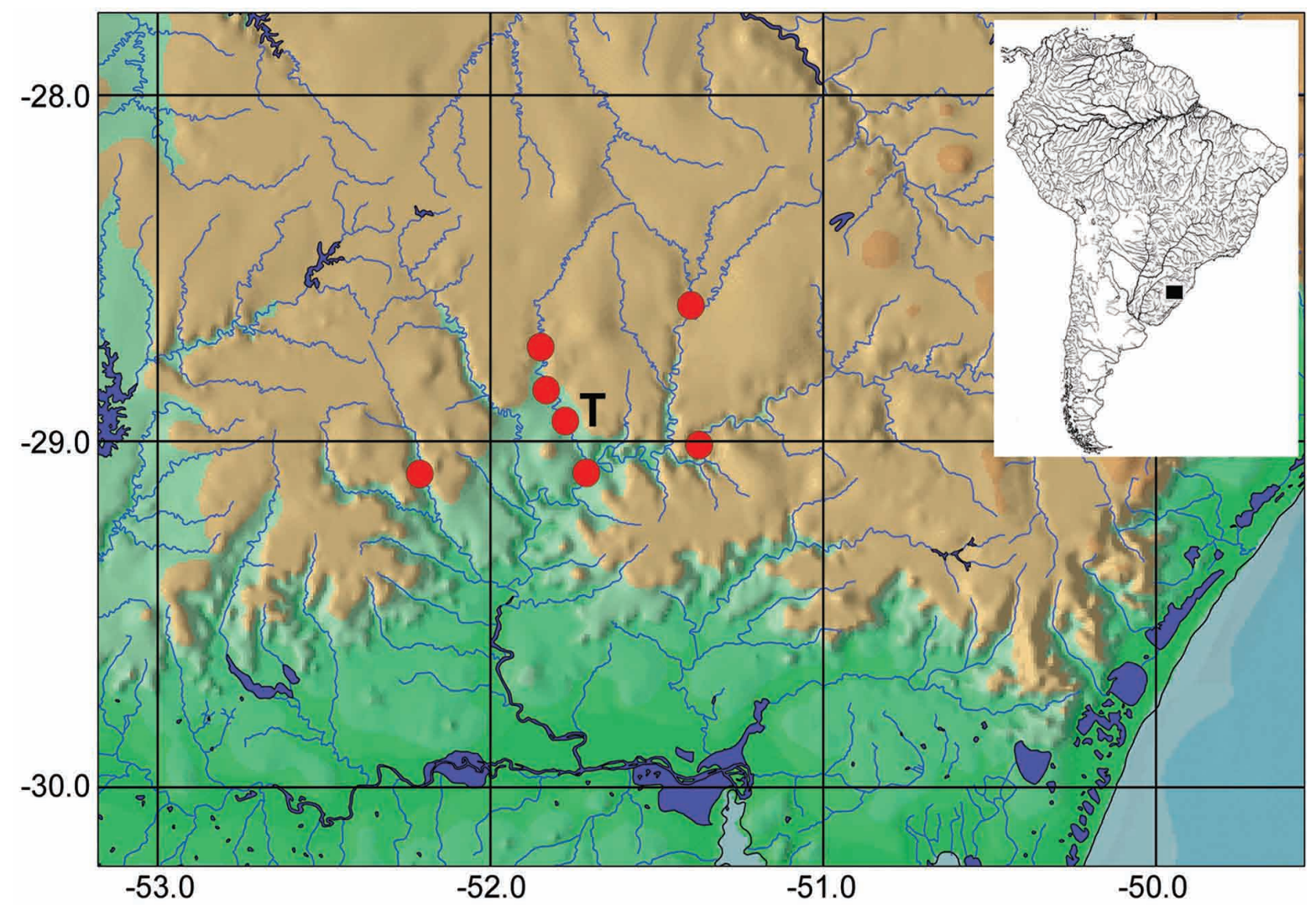

Fig. 3. Map of southern Brazil showing the distribution of the examined material of Astyanax bagual. Some symbols represent more than one lot or locality. $\mathrm{T}=$ type locality.

Etymology. The specific epithet bagual, from TupiGuarani, means wild horse, or what is mortal, or dangerous to mount. This expression is used mainly to convey the information that a given horse is a male reproductive in the countryside of Rio Grande do Sul State. The new species is named in allusion to the presence in mature males of bony hooks on all fins.

Ecological notes. Astyanax bagual was collected in relatively small, dark water rivers up to two meters deep, with stones and rocks on bottom, and moderate riparian vegetation. The collection localities are around 300 meters above sea level. An extensive examination of Astyanax material from fish collections and field expeditions, the species seems to be found only in rivers from mid-slope valleys and in the plateau sections of the Taquari-Antas basin (Fig. 3).

Conservation status. Astyanax bagual is distributed in some of the main tributaries of the rio Taquari-Antas basin, but probably it is further widespread. Despite biological features of that species is unknown, considering the biology of its congeners, there is no imminent known threats to the species. Therefore, according to the International Union for Conservation of Nature (IUCN) categories and criteria (IUCN Standards and Petitions Subcommittee, 2014), $A$. bagual can be classified as Least Concern (LC).

\section{Discussion}

Astyanax bagual is herein assigned to Astyanax according to the definition of the genus given by Eigenmann $(1921,1927)$, which is still often used (Lucena et al., 2013a, 2013b; Ingenito \& Duboc, 2014). The new species shares two of three synapomorphies that define node 200 of Mirande (2010), which included the Astyanax clade and Astyanax paris clade as well as the Aphyocharacinae, Aphyoditeinae, Cheirodontinae, Gymnocharacinae, Stevardiinae, and Bryconamericus scleroparius clade: fourth infraorbital approximately square or more developed longitudinally than dorsoventrally, and coronomeckelian situated mainly dorsal to Meckel cartilage. On the other hand, A. bagual not shares the other synapomorphy that defines that clade, presence of 24 or less branched anal-fin rays. Furthermore, A. bagual has the synapomorphies that define node 268 (Astyanax chico and A. troya clade): presence of bony hooks on all fins. Although the hypothesis of Mirande (2010) is the most comprehensive phylogenetic analysis including the genus Astyanax, it includes only a few species of the genus, which restrict our discussion in terms of relationships among congeners.

The new species recognized herein neither fits the definitions of the species complex Astyanax bimaculatus, diagnosed by the presence of a horizontally elongate 
black humeral spot, two dark vertical bars on the humeral region and a black caudal peduncle spot (Garutti \& Britski, 2000) nor the concept of the A. scabripinnis species group, characterized mainly by a smaller body depth, robust head and body, and reduced number of branched anal-fin rays (Bertaco \& Lucena, 2006).

Among the species of Astyanax that occur in drainages of the La Plata basin and between South and Southeast of Brazil, only four species present similar ranges of branched anal-fin rays and number of maxillary teeth: Astyanax latens Mirande, Aguilera \& Azpelicueta (rio Bermejo basin), A. tupi Azpelicueta, Mirande, Almirón \& Casciotta (rio Paraná basin), A. saguazu (rio Uruguay basin), and $A$. stenohalinus (rio Uruguay basin and laguna do Patos system). The new species differs from these species by the presence of bony hooks on all fin rays (except for A. stenohalinus) vs. hooks present on anal- and pelvicfin rays only, and by the total number of gill-rakers (17-19 vs. 26-27, 24-25, 20-22 and 27-28, respectively); from $A$. latens by the body depth (37.9-45.9\% of SL vs. 34.9-39.1\% of SL); and from A. tupi by the orbital diameter (29.5$38.2 \%$, mean $=34.0$ vs. $35.2-45.2 \%$ of HL, mean $=39.8 \%$ ). See diagnosis for differences between the new species and $A$. saguazu and $A$. stenohalinus. The remaining species of the region either belong to species complexes (e.g., A. bimaculatus, A. scabripinnis) or have distinct counts compared to those found on the new species.

Mature males of Astyanax bagual possess bony hooks on rays of all fins which is considered an uncommon characteristic for characid species (Bertaco et al., 2007; Mirande, 2010). In recent years, new species of Astyanax have been described and/or redescribed with bony hooks on all fins, e.g., A. ojiara Azpelicueta \& Garcia (2000), A stenohalinus by Almirón et al. (2010), and A. hamatilis Camelier \& Zanata (2014), which may suggest that this character should not be considered uncommon, as accurate descriptions of larger series of specimens of different maturity stages are being performed. Therefore, the presence of bony hooks on dorsal and pectoral fins are likely an apomorphic feature within Astyanax and may be potentially used in recovering relationships among species of the genus.

Among the Astyanax species that occur in the rio Taquari-Antas basin (Becker et al., 2013), A. henseli and A. laticeps are the ones with similar counts of maxillary teeth to that of $A$. bagual, but only the latter species possesses bony hooks on rays of all fins of males (vs. bony hooks present only on pelvic- and anal-fin rays). Furthermore, A.bagual can be distinguished from $A$. laticeps by the presence of two vertically elongate humeral spots ( $v s$. one horizontally elongate spot), and by the number of branched anal-fin rays (24-28 vs. 15-23), and from $A$. henseli by the shape of the first humeral spot (see diagnosis), by the caudal peduncle spot (spot wide and expanded dorsally and ventrally $v s$. spot restricted to center of caudal peduncle; see Melo \& Buckup, 2006), and an absence of space between the dentary teeth, which are slender $v s$. presence of space between dentary teeth. In the remaining species, the maxillary is either toothless or usually with a single tooth, rarely two teeth.

Astyanax bagual is confined to the rio Taquari-Antas basin, which is part of the laguna dos Patos system, a freshwater ecoregion recognized by Abell et al. (2008). The upper rio Taquari-Antas basin is recognized as an area of endemism for hosting a large number of endemic taxa (Carvalho \& Reis, 2011; Becker et al., 2013; Ferrer \& Malabarba, 2013; Lucena et al., 2013a, 2013b). According to Becker et al. (2013), species with restricted ranges are potentially more susceptible to environmental impacts and extinction, and they should be considered as targets for assessments in conservation planning and environmental licensing. This is extremely relevant in the upper sections of the Taquari-Antas and Uruguay river basins due to the increasing number of dams implemented for hydroelectric power production and land transformation for forestry and agriculture. In view of these facts we suggest that more intense effort must be focused in the conservation of these river headwaters due to the high degree of endemicity of its fish fauna.

\section{Acknowledgments}

We are grateful to Luiz R. Malabarba and Juliano Ferrer (UFRGS), Carlos A. S. Lucena (PUCRS) for loan of specimens and to Ricardo Ott (FZBRS) for assistance with the figure of the jaws. This paper benefited from comments and criticisms by Fernando R. Carvalho (DZSJRP), Fernando C. Jerep (MZUEL), Tiago P. Carvalho (ANSP) and anonymous referees. VAB was financed by a postdoctoral fellowship from CNPq (Proc. 150042/2009-4), and FAPERGS (Proc. 0903014). ACV was supported by an undergraduate fellowship PIBICCNPq.

\section{References}

Abell, R., M. L. Thieme, C. Revenga, M. Bryer, M. Kottelat, N. Bogutskaya, B. Coad, N. Mandrak, S. Contreras Balderas, W. Bussing, M. L. J. Stiassny, P. Skelton, G. R. Allen, P. Unmack, A. Naseka, R. Ng, N. Sindorf, J. Robertson, E. Armijo, J. V. Higgins, T. J. Heibel, E. Wikramanayake, D. Olson, H. L. López, R. E. Reis, J. G. Lundberg, M. H. SabajPérez \& P. Petry. 2008. Freshwater ecoregions of the world: a new map of biogeographic units for freshwater biodiversity conservation. BioScience, 58: 403-414.

Almirón, A. E., J. R. Casciotta, M. de las M. Azpelicueta \& M. Loureiro. 2010. Redescription of Astyanax stenohalinus Messner, 1926 (Characiformes: Characidae), a poorly known species from Argentina and Uruguay. Zootaxa, 2434: 60-68.

Azpelicueta, M. de las M. \& J. O. García. 2000. A new species of Astyanax (Characiformes, Characidae) from Uruguay river basin in Argentina, with remarks on hook presence in Characidae. Revue suisse de Zoologie, 107: 245-257. 
Becker, F. G., L. C. C. de Fries, J. Ferrer, V. A. Bertaco, K. D. G. Luz-Agostinho, J. F. P. Silva, A. R. Cardoso, Z. M. S. Lucena \& C. A. S. Lucena. 2013. Fishes of the Taquarí-Antas River basin (Patos Lagoon basin), southern Brazil. Brazilian Journal of Biology, 73: 79-90.

Bertaco, V. A. 2014. Astyanax douradilho, a new characid fish from the rio Tramandaí system, southern Brazil (Characiformes: Characidae). Zootaxa, 3794: 492-500.

Bertaco, V. A. \& C. A. S. Lucena. 2006. Two new species of Astyanax (Ostariophysi: Characiformes: Characidae) from eastern Brazil, with a synopsis of the Astyanax scabripinnis species complex. Neotropical Ichthyology, 4: 53-60.

Bertaco, V. A. \& C. A. S. Lucena. 2010. Redescription of Astyanax obscurus (Hensel, 1870) and A. laticeps (Cope, 1894) (Teleostei: Characidae): two valid freshwater species originally described from rivers of Southern Brazil. Neotropical Ichthyology, 8: 7-20.

Bertaco, V. A., L. R. Malabarba \& J. A. Dergam. 2007. New Hyphessobrycon from the upper rio Pardo drainage in eastern Brazil (Teleostei: Characiformes: Characidae). Neotropical Ichthyology, 5: 245-249.

Burns, J. R. \& S. H. Weitzman. 1996. Novel gill-derived gland in the male swordtail characin, Corynopoma riisei (Teleostei: Characidae: Glandulocaudinae). Copeia, 3: 627-633.

Camelier, P. \& A. M. Zanata. 2014. A new species of Astyanax Baird \& Girard (Characiformes: Characidae) from the rio Paraguaçu basin, Chapada Diamantina, Bahia, Brazil, with comments on bony hooks on all fins. Journal of Fish Biology, 84: 475-490.

Carvalho, T. P. \& R. E. Reis. 2011. Taxonomic review of Hisonotus Eigenmann \& Eigenmann (Siluriformes: Loricariidae: Hypoptopomatinae) from the laguna dos Patos system, southern Brazil. Neotropical Ichthyology, 9: 1-48.

Eigenmann, C. H. 1921. The American Characidae. Part 3. Memoirs of the Museum of Comparative Zoology, 43: 209310 .

Eigenmann, C. H. 1927. The American Characidae. Part 4. Memoirs of the Museum of Comparative Zoology, 43: 311428.

Eschmeyer, W. N. (Ed.). 2014. Catalog of fishes. Eletronic version -27 August 2014. California Academy of Sciences. Available from http://research.calacademy.org/research/ichthyology/ catalog/fishcatmain.asp (Date of acess - 28 August 2014).

Ferrer, J. \& L. R. Malabarba. 2013. Taxonomic review of the genus Trichomycterus Valenciennes (Siluriformes: Trichomycteridae) from the Laguna dos Patos system, southern Brazil. Neotropical Ichthyology, 11: 217-246.

Fink, W. L. \& S. H. Weitzman. 1974. The so-called cheirodontin fishes of Central America with descriptions of two new species (Pisces: Characidae). Washington, DC, Smithsonian Institution Press. 46p. (Smithsonian Contributions to Zoology, n. 172).
Garutti, V. \& H. A. Bristki. 2000. Descrição de uma espécie nova de Astyanax (Teleostei: Characidae) da bacia do alto rio Paraná e considerações sobre as demais espécies do gênero na bacia. Comunicações do Museu de Ciências da PUCRS. Série Zoologia, 13: 65-88.

Ingenito, L. F. S. \& L. F. Duboc. 2014. A new species of Astyanax (Ostariophysi: Characiformes: Characidae) from the upper rio Iguaçu basin, southern Brazil. Neotropical Ichthyology, 12: 281-290.

IUCN Standards and Petitions Subcommittee. 2014. Guidelines for using the IUCN Red List Categories and Criteria. Version 11. Prepared by the Standards and Petitions Subcommittee. Available from http://www.iucnredlist.org/documents/ RedListGuidelines.pdf (Date of access - 26 May 2015).

Javonillo, R., L. R. Malabarba, S. H. Weitzman \& J. R. Burns. 2010. Relationships among major lineages of characid fishes (Teleostei: Ostariophysi: Characiformes), based on molecular sequence data. Molecular Phylogenetics and Evolution, 54: 498-511.

Lucena, C. A. S., V. A. Bertaco \& G. Berbigier. 2013a. A new species of Astyanax from headwater streams of southern Brazil (Characiformes: Characidae). Zootaxa, 3700: 226236.

Lucena, C. A. S., J. B. Castro \& V. A. Bertaco. 2013b. Three new species of Astyanax from drainages of southern Brazil (Characiformes: Characidae). Neotropical Ichthyology, 11: 537-552.

Melo, F. A. G. \& P. A. Buckup. 2006. Astyanax henseli, a new name for Tetragonopterus aeneus Hensel, 1870 from southern Brazil (Teleostei: Characiformes). Neotropical Ichthyology, 4: 45-52.

Mirande, J. M. 2010. Phylogeny of the family Characidae (Teleostei: Characiformes): from characters to taxonomy. Neotropical Ichthyology, 8: 385-568.

Oliveira, C., G. S. Avelino, K. T. Abe, T. C. Mariguela, R. C. Benine, G. Ortí, R. P. Vari \& R. M. C. Castro. 2011. Phylogenetic relationships within the speciose family Characidae (Teleostei: Ostariophysi: Characiformes) based on multilocus analysis and extensive ingroup sampling. BMC Evolutionary Biology, 11: 275 (1-25).

Taylor, W. R. \& G. C. van Dyke. 1985. Revised procedures for staining and clearing small fishes and other vertebrates for bone and cartilage study. Cybium, 9: 107-119.

Terán, G. E., S. Mangione \& J. M. Mirande. 2014. Gill-derived glands in species of Astyanax (Teleostei: Characidae). Acta Zoologica (Stockholm), 00: 1-8.

Submitted September 03, 2014 Accepted February 08, 2015 by George Mattox Published June 30, 2015 
